\title{
A Scalable, Chromatography-Free Synthesis of Benzotetramisole
}

\author{
David S. B. Daniels ${ }^{a}$ \\ Siobhan R. Smith ${ }^{a}$ \\ Tomas Leb| ${ }^{\mathrm{a}}$ \\ Peter Shapland ${ }^{b}$ \\ Andrew D. Smith*a \\ a School of Chemistry, University of St Andrews, North Haugh, \\ St Andrews, Fife KY16 9ST, UK \\ ads10@st-andrews.ac.uk \\ ${ }^{b}$ GSK, Gunnels Wood Road, Stevenage, Hertfordshire, SG1 2NY, \\ UK
}

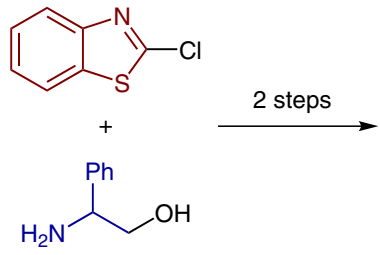

$(R),(S)$ and $( \pm)$

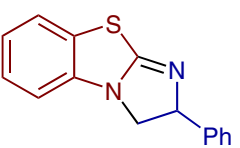

$(R)-,(S)$ - and ( \pm )-BTM ca. $60 \%$ yield $10 \mathrm{~g}$ scale chromatography-free
Received: 22.08.2014

Accepted after revision: 17.10.2014

Published online: 21.11 .2014

DOI: 10.1055/s-0034-1378931; Art ID: ss-2014-t0523-psp

Abstract The scalable, chromatography-free synthesis of the chiral isothiourea benzotetramisole (BTM) in two steps from commercially available materials is presented. A detailed procedure for the synthesis of both enantiomers and the racemate on ca. 10 gram scale is disclosed.

Key words isothiourea, Lewis base catalysis, asymmetric catalysis, kinetic resolution, rearrangement, benzotetramisole

\section{Introduction}

Isothioureas are an important class of Lewis base that are becoming increasingly used within a range of organocatalytic procedures. ${ }^{1}$ This molecular class came to prominence in organocatalysis with the seminal report by Birman and Li in $2006^{2}$ that demonstrated their power as acyl transfer catalysts in the kinetic resolution of secondary alcohols. The most potent and selective catalyst in this study was benzotetramisole (BTM), the benzannulated derivative of the antihelminthic pharmaceutical tetramisole ${ }^{3}$ that itself is a competent catalyst for this transformation. Based upon the isothiourea catalyst motif, further derivatisations of the heterocyclic core, including changes to ring size and substitution pattern, have led to a series of powerful dihydropyrimido[2,1-b]benzothiazole-based catalysts that have been applied to a range of transformations (Figure 1). ${ }^{4}$<smiles>c1ccc([C@H]2CN3CCSC3=N2)cc1</smiles>

(S)-tetramisole<smiles>Cc1cc(C)c(C2CCN=C3Sc4cccc(C)c4N32)c(C)c1</smiles>

(S)-4-Mes-DHPB<smiles>c1ccc([C@H]2CN3C(=N2)Sc2ccccc23)cc1</smiles>

(R)-benzotetramisole (BTM)<smiles></smiles>

$(S, R)$-HBTM-2.1

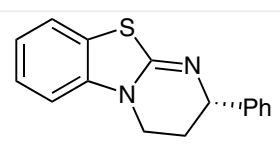

(S)-homobenzotetramisole (HBTM)<smiles>CC1CN2C(=NC1c1ccccc1)Sc1ccccc12</smiles>

$(S, R)$-HBTM-2
Figure 1 A selection of isothiourea catalysts

The power of BTM (4) as a highly enantioselective acyl transfer catalyst has been further demonstrated by Birman, ${ }^{5}$ Shiina, ${ }^{6}$ and others ${ }^{7}$ in a range of kinetic resolution processes. Similarly, BTM has found use in an asymmetric Steglich rearrangement ${ }^{8}$ and the kinetic resolution of secondary alcohols by silylation. ${ }^{9}$ The reports by Romo and coworkers on the nucleophile-catalysed aldol-lactonisation<smiles>Clc1nc2ccccc2s1</smiles><smiles>NC(CO)c1ccccc1</smiles>

(R)-, (S)- or $( \pm)-2$

(1.0 equiv)

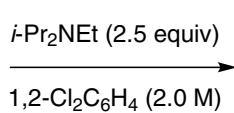

$195^{\circ} \mathrm{C}, 24 \mathrm{~h}$

(1.05 equiv)

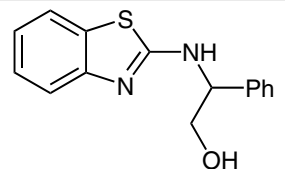

$(R)-,(S)$ - or $( \pm)-3$ 13.91-14.81 g, 74-79\%
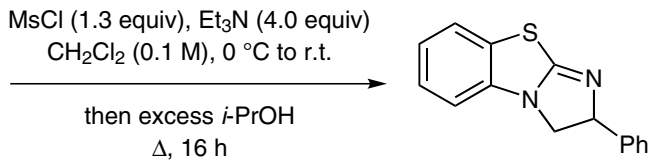

$(R)-,(S)-$ or $( \pm)-4$ (BTM) $8.90-11.37 \mathrm{~g}, 73-84 \%$

Scheme 1 A practical, multigram synthesis of benzotetramisole (BTM; 4 ) 


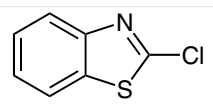

1<smiles>[GeH2]OC=[GeH2]</smiles>

$+$<smiles>N[C@@H](CO)c1ccccc1</smiles>

$(R)-2$ (1.03 equiv)

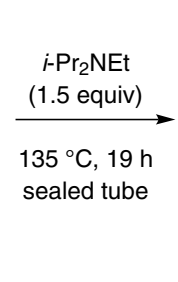<smiles>OCC(Nc1nc2ccccc2s1)c1ccccc1</smiles>

$(R)-3$

$83 \%$ after chromatography

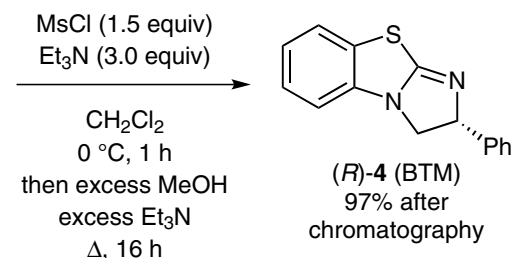

Scheme 2 Birman's original procedure for the synthesis of $(R)-\mathbf{4}^{1}$

(NCAL) reaction using ammonium enolates, generated initially from cinchona alkaloids ${ }^{10}$ and later using isothioureas, ${ }^{11}$ stimulated our group to further demonstrate that isothioureas serve as excellent Lewis base organocatalysts for these processes. ${ }^{12}$ BTM (4) in particular has enabled the catalytic enantioselective synthesis of dihydropyridones ${ }^{12 \mathrm{c}}$ and $\beta$-lactams, ${ }^{12 \mathrm{j}}$ as well as promoting the asymmetric [2,3]-rearrangement of allylic ammonium ylides. ${ }^{13}$ Romo and co-workers have also reported the use of BTM (4) in the asymmetric synthesis of bicyclic lactones. ${ }^{14}$

While tetramisole is commercially available at reasonable cost and a scalable route to HBTM-2.1 has been reported, ${ }^{12 \mathrm{~d}}$ in our hands, Birman's original procedure (detailed in Scheme 2) was suitable for the synthesis of (R)-BTM on ca. $1 \mathrm{~g}$ scale. ${ }^{2}$ Although this sequence was reproduceable, in practice we found this sequence to be limited by the use of a sealed tube in the first step, chromatographic purifications to obtain both $(R)-\mathbf{3}$ and noncrystalline $(R)-\mathbf{4}$, and multiple recrystallisations to obtain pure material.

Further syntheses of BTM have been reported,7a-c,15 based upon this original procedure. ${ }^{2}$ Incremental improvements have been made by Chen and co-workers, finding firstly that intermediate $\mathbf{3}$ can be purified by recrystallisation from chloroform, ${ }^{7 a}$ and secondly that the two reactions could be performed sequentially in 'one-pot' without isolation of $3 .{ }^{15}$ However, chromatography and recrystallisation were still required to furnish pure BTM and the final yield of crystalline material was not disclosed. Recently, Okamoto and co-workers reported a conceptually different four-step synthesis of BTM starting from $o$-bromoaniline. ${ }^{16}$

Although $(R)$ - and $(S)-\mathbf{4}$ are now commercially available (ca. $£ 90 / 1 \mathrm{~g}$ ), ${ }^{17}$ the need for multi-gram quantities of racemic and enantiopure BTM (4) to support our investigations into its use in catalysis motivated the development of a scalable, operationally simple synthesis. Herein we report the multi-gram synthesis of $(R)-,(S)$ - and $( \pm)-\mathbf{4}$ from commercially available 2-chlorobenzothiazole (1) and 2phenylglycinol (2) without recourse to chromatographic purifications (Scheme 1).

\section{Scope and Limitations}

First, the neat reaction between 2-chlorobenzothiazole (1), 2-phenylglycinol (2) and ethyldiisopropylamine to form 3 was optimised. The use of a high-boiling co-solvent (chlorobenzene at reflux) whilst maintaining high concentrations of 1 (ca. $2.0 \mathrm{M}$ ) allowed the reaction to be performed in standard glassware under air without the need for sealed tubes or an inert atmosphere. However, extended reaction times $\left(>48 \mathrm{~h}\right.$ ) at reflux $\left(\mathrm{ca} .140^{\circ} \mathrm{C}\right)$ were required for high conversions of $\mathbf{1}$ as measured by GC analysis. Switching to 1,2-dichlorobenzene and increasing the reflux temperature (ca. $195^{\circ} \mathrm{C}$ ) led consistently and reproducibly to $>95 \%$ conversion of 1 after 24 hours (Scheme 3, a). Reducing the temperature, equivalents of ethyldiisopropylamine, or diluting the reaction further led to lower conversions and extended reaction times.

Chen $^{7 \mathrm{a}, \mathrm{b}}$ and Nagano ${ }^{7 \mathrm{e}}$ observed precipitation of product $\mathbf{3}$ in the separatory funnel during aqueous workup of the reaction. Seeking to exploit this to improve the workup procedure, the reaction mixture was diluted with water resulting in the formation of a thick paste. Upon addition of an organic solvent (e.g., hexanes or dichloromethane), large amounts of a fine solid precipitate of $\mathbf{3}$ were formed. This could be collected by filtration, followed by washing with further portions of organic solvent to leave crude $\mathbf{3}$ as a tan solid. In our hands, recrystallisation from hot chloroform as detailed by Chen ${ }^{7 a}$ returned the chloroform adduct of $\mathbf{3}$, from which residual chloroform could not be removed even after extended periods under reduced pressure. Multiple cycles of re-slurrying the solid with dichloromethane followed by evaporation of the solvent allowed the isolation of solid 3 that was pure by ${ }^{1} \mathrm{H}$ and ${ }^{13} \mathrm{C}\left\{{ }^{1} \mathrm{H}\right\}$ NMR analysis (Scheme 3, b).

This material contained variable amounts of water as evidenced by droplets present during recrystallisation and slurrying. This water was not purged by filtration and had a detrimental effect on the subsequent step. The azeotropic removal of water from $\mathbf{3}$ was achieved through heating a suspension of $\mathbf{3}$ at reflux in toluene using a Dean-Stark apparatus. However, 3 was observed to dissolve in toluene at reflux, so direct recrystallisation of crude $\mathbf{3}$ from toluene in a Dean-Stark apparatus was considered as a possible sim- 
a)

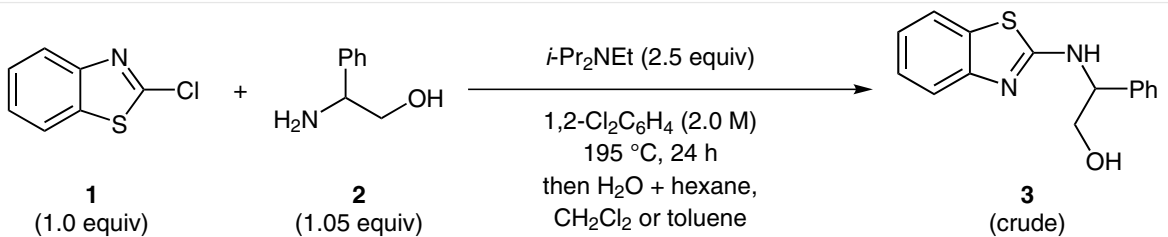

b)

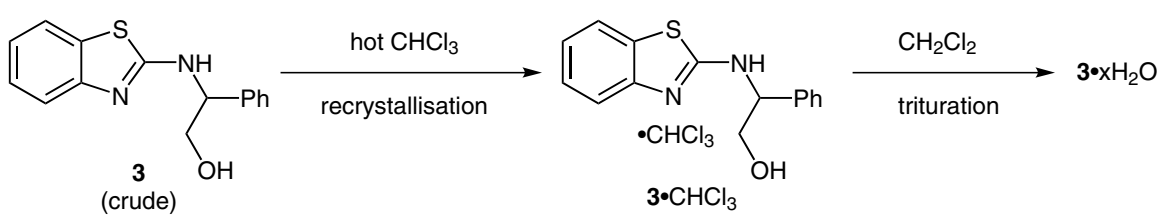

c)<smiles>OCC(Nc1nc2ccccc2s1)Pc1ccccc1</smiles><smiles>OCC(Nc1nc2ccccc2s1)c1ccccc1</smiles>

from $10.00 \mathrm{~g} 2$ :

Scheme 3 Optimisation of the first step

plification to access analytically pure, anhydrous 3. Using this process and starting from 10.00 grams of $(R)-,(S)-$, or $( \pm)-2,{ }^{18}$ this procedure gave analytically pure, fluffy white crystals of 3 consistently in 74-79\% yield after one or two recrystallisations from hot toluene in a Dean-Stark apparatus (Scheme 3, c). ${ }^{19}$

With large quantities of $\mathbf{3}$ easily accessible, the transformation of the alcohol functionality and cyclisation into BTM 4 was examined. Employing Birman's conditions of methanesulfonyl chloride and triethylamine (Scheme 2) followed by aqueous workup yields a yellow gum which, although relatively pure by ${ }^{1} \mathrm{H}$ NMR analysis, proved difficult to transform into high yields of crystalline BTM by trituration or recrystallisation without recourse to chromatography. This tentatively suggested the presence of polymeric impurities that were largely silent by ${ }^{1} \mathrm{H}$ NMR analysis. Therefore, alternative activation methods for the alcohol cyclisation were examined.

Both tosyl chloride and thionyl chloride gave unsatisfactory results, with the former giving a complex mixture of products and the latter incomplete conversion of $\mathbf{3}$ (Scheme 4). Interestingly, the reaction of $\mathbf{3}$ under Mitsonobu conditions resulted in skeletal rearrangement to give isomeric isothiourea $\mathbf{5}$ as the major species. The structure was inferred by comparison of the crude ${ }^{1} \mathrm{H}$ NMR spectra to that reported by Okamoto and co-workers. ${ }^{4}$ This unexpected reactivity was not pursued further, and the fidelity of stereochemical transfer was not determined.

As alternative activating agents were ultimately unsuccessful, efforts were focused upon understanding and improving the reaction of $\mathbf{3}$ with methanesulfonyl chloride. It was found that $>1.25$ equivalents of methanesulfonyl chlo-

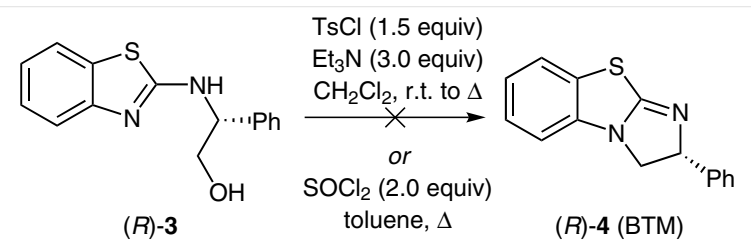

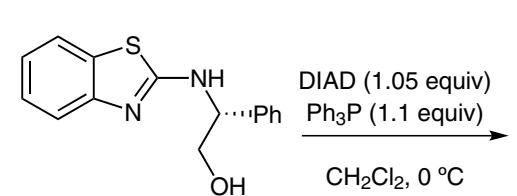

$(R)-3$

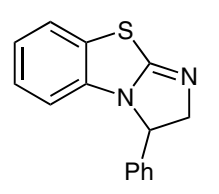

5
Scheme 4 Alternative activating agents for the cyclisation of 3

ride were required for complete consumption of $\mathbf{3}$, even with freshly distilled methanesulfonyl chloride under strictly anhydrous conditions. TLC and ${ }^{1} \mathrm{H}$ NMR analysis of the reaction mixture indicated the formation of two products. Attempted chromatographic isolation of the two species failed to allow isolation of purported $\mathrm{O}$-mesylate $\mathbf{6}$ owing to its instability on silica gel. However, a second $\mathrm{N}, \mathrm{O}$ bis-mesylate species 7 was isolated and characterised (Scheme 5). Treating 3 with $>2$ equivalents of methanesulfonyl chloride allowed 7 to be produced exclusively without any of the alternative isomeric $\mathrm{N}, \mathrm{O}$-bis-mesylate being observed. ${ }^{20}$ Interestingly, heating a dichloromethane solution of 7 at reflux in the presence of triethylamine and methanol overnight gave BTM 4 as the sole product in excellent yield after chromatography. This observation suggests that under Birman's original conditions a mixture of mono- and bismesylate $\mathbf{6}$ and $\mathbf{7}$ forms with complete consumption of 
$(R)-3$

$(R)-3$

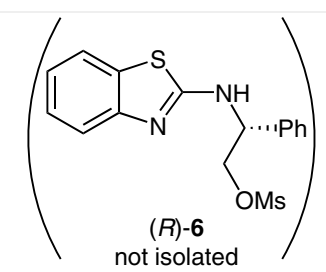

$+$<smiles>COCC(/N=c1/sc2ccccc2n1C)c1ccccc1</smiles>

$(R)-7$<smiles>c1ccc([C@H]2CN3C(=N2)Sc2ccccc23)cc1</smiles>

(R)-4 (BTM) $89 \%$ after chromatography

Scheme 5 Synthesis and cyclisation of N,O-bis-mesylate 7

methanesulfonyl chloride. Both components of this mixture cyclise upon heating with base to give $\mathbf{4}$ exclusively, with the sulfene eliminated from the cyclisation of bis-mesylate 7 quenched by methanol. ${ }^{21}$ Indeed, if a nucleophilic co-solvent is absent the reaction turns black and the isolable yield of BTM 4 is significantly reduced.

With this information in hand, optimised conditions for the cyclisation were established (Scheme 6). A suspension of 3 and excess triethylamine (4.0 equiv) in anhydrous dichloromethane $(0.1 \mathrm{M})$ was cooled in an ice/water bath. A slight excess of methanesulfonyl chloride (1.3 equiv) was added, sufficient to completely consume 3 . The resulting solution was treated with isopropanol, ${ }^{22}$ heated to reflux overnight, and checked for completion by ${ }^{1} \mathrm{H}$ NMR analysis. These conditions consistently led to full conversion of $\mathbf{3}$ into crude 4. An improved workup procedure was sought to avoid chromatography, with the Brønsted basic nature of 4 considered an exploitable property through acid/base extractions. Hence, the reaction was quenched with aqueous $1 \mathrm{M}$ sodium hydroxide to remove acidic impurities ( $\mathrm{MsOH}$, etc.) and the dichloromethane layer extracted multiple times with aqueous $1 \mathrm{M}$ hydrochloric acid to leave an aqueous solution of BTM. $\mathrm{HCl}(\mathbf{4} \cdot \mathrm{HCl})$. Basification (aq $2 \mathrm{M} \mathrm{NaOH}$, $\mathrm{pH}>14$ ) of the combined aqueous layers, extraction with an organic solvent (EtOAc, $\mathrm{Et}_{2} \mathrm{O}$, etc.), and concentration afforded solid 4 that was reasonably pure in ca. 50\% yield. This material could be triturated or recrystallised from diethyl ether-hexanes to give analytically pure 4, demonstrating that a chromatography-free route was plausible. However, the loss of material was concerning until it was discovered that $\mathrm{BTM} \cdot \mathrm{HCl}$ is highly soluble in dichloromethane, with multiple extractions with aqueous $1 \mathrm{M}$ hydrochloric acid failing to completely remove it from the organic layer. A solvent switch from dichloromethane to diethyl ether (in which $\mathrm{BTM} \cdot \mathrm{HCl}$ is only sparingly soluble) was performed after the aqueous $1 \mathrm{M}$ sodium hydroxide wash and this greatly increased the mass recovery of crude $\mathbf{4}$ after the acid/base extractions. Final modifications to the workup in- cluded a toluene azeotrope during the solvent switch to remove the remaining triethylamine, and treatment of the final organic solution of $\mathbf{4}$ with charcoal to decolourise it. Finally, trituration of the crude with hot diethyl ether provided analytically pure BTM (4) in consistently high yield for both enantiomers and the racemate of $73-84 \%$ from 3 (Scheme 6).

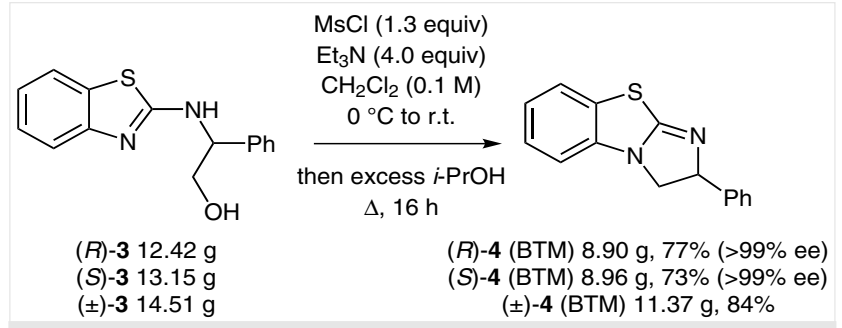

Scheme 6 Optimised conditions of the synthesis of BTM (4)

In conclusion, the scalable, chromatography-free, and operationally simple synthesis of the isothiourea organocatalyst BTM has been demonstrated. The transformation of intermediate $\mathbf{3}$ with methanesulfonyl chloride has also been investigated, showing that both mono- and bismesylates $\mathbf{6}$ and $\mathbf{7}$ will cyclise to form BTM under the reaction conditions.

Reactions were performed in oven-dried glassware, using DrySyn ${ }^{\circledR}$ blocks for heated reactions. Anhydrous $\mathrm{CH}_{2} \mathrm{Cl}_{2}$ was obtained from an MBraun SPS-800 system. 2-Chlorobenzothiazole was fractionally distilled under reduced pressure prior to use, $i-\mathrm{Pr}_{2} \mathrm{NEt}$ and $\mathrm{Et}_{3} \mathrm{~N}$ were stored over $\mathrm{KOH}$ pellets, and $\mathrm{MsCl}$ was distilled under reduced pressure from $\mathrm{P}_{2} \mathrm{O}_{5}$ prior to use and stored in a fridge under $\mathrm{N}_{2} \cdot{ }^{23}$ All other solvents and commercial reagents were used as received without further purification. Petroleum ether (PE) used refers to the fraction boiling in the $40-60{ }^{\circ} \mathrm{C}$ range. Analytical TLC was performed on precoated aluminum plates (Kieselgel $60 \mathrm{~F}_{254}$ silica). Plates were visualised under UV light ( $254 \mathrm{~nm}$ ) or by staining with $\mathrm{KMnO}_{4}$ followed by heating. Flash column chromatography was performed on Kieselgel 
60 silica in the solvent system stated. Melting points were recorded on an Electrothermal 9100 melting point apparatus. Optical rotations were measured on a PerkinElmer Precisely/Model-341 polarimeter operating at the sodium D line with a $100 \mathrm{~mm}$ path cell at $20^{\circ} \mathrm{C}$. HPLC analyses were obtained on a Shimadzu HPLC using a Chiralpak AD-H column. GC analyses were obtained on a Shimadzu GC-2025, with He as the carrier gas in split injection mode at constant linear velocity. An Agilent DB-5 analytical column was used for analyses $(30 \mathrm{~m}, 0.25$ $\mathrm{mm}$ ID, $0.5 \mu \mathrm{m}$ film thickness). IR spectra were recorded on a Shimadzu IRAffinity-1 Fourier transform IR spectrophotometer using a Pike MIRacle ATR accessory. ${ }^{1} \mathrm{H}$ and ${ }^{13} \mathrm{C}\left\{{ }^{1} \mathrm{H}\right\}$ NMR spectra were acquired on Bruker 500 or $400 \mathrm{MHz}$ spectrometers. Chemical shifts ( $\delta$ ) are quoted in parts per million (ppm) and are referenced to the residual solvent peak $\left({ }^{1} \mathrm{H}: \mathrm{CDCl}_{3} 7.26 \mathrm{ppm}, \mathrm{MeOH}-d_{4} 3.31 \mathrm{ppm} ;{ }^{13} \mathrm{C}: \mathrm{CDCl}_{3} 77.16 \mathrm{ppm}\right.$, $\left.\mathrm{MeOH}-d_{4} 49.00 \mathrm{ppm}\right)$. Coupling constants $(J)$ are quoted to the nearest $0.1 \mathrm{~Hz}$. Mass spectrometry (HRMS) data were acquired by electrospray ionisation (ESI) at the EPSRC UK National Mass Spectrometry Facility at Swansea University. Elemental analysis (CHN) was performed by Mr. Stephen Boyer at London Metropolitan University.

\section{(R)-(-)-2-(Benzo[d]thiazol-2-ylamino)-2-phenylethanol [(R)-3]}

A $250 \mathrm{~mL}$ round-bottomed flask containing a stirrer bar was charged with $(R)$-2-phenylglycinol [( $R)-2 ; 10.00 \mathrm{~g}, 72.80 \mathrm{mmol}, 1.05$ equiv), 0 dichlorobenzene ( $34.5 \mathrm{~mL}, 2.0 \mathrm{M}$ ), $i-\mathrm{Pr}_{2} \mathrm{NEt}$ ( $31.0 \mathrm{~mL}, 173.6 \mathrm{mmol}, 2.5$ equiv), and 2-chlorobenzothiazole (1; $8.60 \mathrm{~mL}, 69.43 \mathrm{mmol}, 1.0$ equiv). The resulting yellow suspension was stirred vigorously and heated to reflux at $195{ }^{\circ} \mathrm{C}$ (DrySyn ${ }^{\circledR}$ temperature), at which point the suspended solid had dissolved to leave a yellow solution. After $24 \mathrm{~h}$ at reflux, ${ }^{24}$ the orange reaction mixture was allowed to cool to r.t. Once cooled, the mixture was diluted with distilled $\mathrm{H}_{2} \mathrm{O}(100 \mathrm{~mL})$ and toluene $(75 \mathrm{~mL})$ with vigorous stirring. A precipitate formed over the next $15 \mathrm{~min}$ and stirring was maintained for a further $1 \mathrm{~h}$. The reaction mixture was filtered through a $1.0 \mathrm{~L}$ sintered glass filter funnel (porosity 3 ) under vacuum to leave the solid precipitate. The solid was washed with toluene $(2 \times 100 \mathrm{~mL})$ and dried on the sinter under vacuum for 30 min until a free-flowing powder was obtained. The crude product (typically $22-24 \mathrm{~g}$ ) was transferred to a $500 \mathrm{~mL}$ round-bottomed flask containing a stirrer bar, followed by toluene $(100 \mathrm{~mL})$. A $10 \mathrm{~mL}$ Dean-Stark trap filled with toluene and a reflux condenser were fitted to the flask, and the suspension heated to reflux $\left(180^{\circ} \mathrm{C}\right.$ DrySyn $^{\circledR}$ temperature). Once at reflux, further $10 \mathrm{~mL}$ portions of toluene were added down the condenser, waiting $~ 5$ min between portions, until a clear solution was obtained (4-6 portions were typically needed). The reflux was maintained until no further $\mathrm{H}_{2} \mathrm{O}$ was observed condensing into the trap (typically 30 min were sufficient). The flask was removed from the heating block and allowed to cool slowly to r.t., over which time a precipitate formed. Once cooled, the flask was further cooled to $-10{ }^{\circ} \mathrm{C}$ in a $\mathrm{NaCl} /$ ice/water bath for $30 \mathrm{~min}$. The solid precipitate was recovered by vacuum filtration on a $1.0 \mathrm{~L}$ sintered glass filter funnel (porosity 3 ), and washed with further portions of toluene $(2 \times 100 \mathrm{~mL})$. The solid was dried on the sinter under vacuum for $30 \mathrm{~min}$, then transferred to a $250 \mathrm{~mL}$ round-bottomed flask and dried in vacuo to constant weight. This gave title compound (R)-3 as fluffy white crystals; yield: $14.81 \mathrm{~g}$ (54.78 mmol, 79\%). A second recrystallisation from toluene at reflux may be required if a powder is obtained from the first attempt. Typical mass loss on second recrystallisation was $<500 \mathrm{mg}$ on this scale; $\mathrm{mp} 158-159{ }^{\circ} \mathrm{C}$ (toluene) [Lit. $\left.^{7 \mathrm{~b}} 159-160{ }^{\circ} \mathrm{C}\left(\mathrm{CHCl}_{3}\right)\right] ;[\alpha]_{\mathrm{D}}{ }^{20}-102.7$ (c 1.04, MeOH) $\left\{\right.$ Lit. $^{7 \mathrm{~b}}[\alpha]_{\mathrm{D}}$ -103 (c 1.17, $\mathrm{MeOH})$.
GC [Agilent DB-5, $40 \mathrm{~cm} / \mathrm{s}$ (He), inj. temp $250{ }^{\circ} \mathrm{C}$, FID temp $325^{\circ} \mathrm{C}$; temp profile: initial $120^{\circ} \mathrm{C}(2 \mathrm{~min})$, then ramp to $320^{\circ} \mathrm{C}\left(20^{\circ} \mathrm{C} / \mathrm{min}\right.$, hold $5 \mathrm{~min}$ ), total run $=17 \mathrm{~min}]: t_{\mathrm{R}} i$ - $\mathrm{Pr}_{2} \mathrm{NEt}, 1.87 \mathrm{~min}$; 0 -dichlorobenzene, $3.20 \mathrm{~min}$; 2-phenylglycinol (2), $5.34 \mathrm{~min}$; 2-chlorobenzothiazole (1), $5.74 \mathrm{~min} ; \mathbf{3}, 12.56 \mathrm{~min}$.

HPLC (Chiralcel AD-H, 10\% $i$-PrOH-hexane, $1.5 \mathrm{~mL} / \mathrm{min}, 40{ }^{\circ} \mathrm{C}, 254$ $\mathrm{nm}): t_{\mathrm{R}} 13.75 \min (100 \%),>99 \%$ ee.

${ }^{1} \mathrm{H}$ NMR $\left(500 \mathrm{MHz}, \mathrm{MeOH}-d_{4}\right): \delta=3.80[1 \mathrm{H}, \mathrm{dd}, J=11.4,7.4 \mathrm{~Hz}$, $\mathrm{C}(1) \mathrm{H}^{A} \mathrm{H}^{\mathrm{B}}$ ], $3.85\left[1 \mathrm{H}, \mathrm{dd}, J 11.4,5.0 \mathrm{~Hz}, \mathrm{C}(1) \mathrm{H}^{\mathrm{A}} \mathrm{H}^{\mathrm{B}}\right], 5.00[1 \mathrm{H}, \mathrm{dd}, J=7.4$, $5.0 \mathrm{~Hz}, \mathrm{C}(2) \mathrm{H}], 7.03(1 \mathrm{H}, \mathrm{td}, J=7.5,1.1 \mathrm{~Hz}, \mathrm{ArH}), 7.22(1 \mathrm{H}, \mathrm{td}, J=7.5$, $1.2 \mathrm{~Hz}, \mathrm{ArH}), 7.26(1 \mathrm{H}, \mathrm{t}, J=7.4 \mathrm{~Hz}, p-\mathrm{PhH}), 7.34(2 \mathrm{H}, \mathrm{t}, J=7.4 \mathrm{~Hz}, m-$ $\mathrm{PhH}), 7.38(1 \mathrm{H}, \mathrm{d}, J=8.1 \mathrm{~Hz}, \mathrm{ArH}), 7.44(2 \mathrm{H}, \mathrm{d}, J=7.4 \mathrm{~Hz}, 0-\mathrm{PhH}), 7.55$ $(1 \mathrm{H}, \mathrm{d}, J=7.8 \mathrm{~Hz}, \mathrm{ArH})$.

${ }^{13} \mathrm{C}\left\{{ }^{1} \mathrm{H}\right\}$ NMR $\left(126 \mathrm{MHz}, \mathrm{MeOH}-d_{4}\right): \delta=62.2,66.9,119.0,121.7,122.7$, 126.8, 128.1, 128.6, 129.5, 131.3, 141.1, 153.0, 169.0.

Anal. Calcd for $\mathrm{C}_{15} \mathrm{H}_{14} \mathrm{~N}_{2} \mathrm{OS}$ : C, 66.64; H, 5.22; N, 10.36. Found: C, 66.57; H, 5.31; N, 10.33 .

${ }^{1} \mathrm{H}$ and ${ }^{13} \mathrm{C}$ NMR data were consistent with literature values. ${ }^{1}$

\section{(S)-(+)-2-(Benzo[d]thiazol-2-ylamino)-2-phenylethanol [(S)-3]}

An identical procedure to that outlined for $(R)$-3 using (S)-2-phenylglycinol $[(S)-2 ; 10.00 \mathrm{~g}, 72.80 \mathrm{mmol}]$ gave the title compound $(S)-3$ as fluffy white crystals after a second recrystallisation; yield: $13.91 \mathrm{~g}$ (51.45 mmol, 74\%); mp $158-159^{\circ} \mathrm{C}$ (toluene); $[\alpha]_{D}{ }^{20}+101.7$ (c 1.01, $\mathrm{MeOH})$.

HPLC (Chiralcel AD-H, 10\% $i$-PrOH-hexane, $1.5 \mathrm{~mL} / \mathrm{min}, 40{ }^{\circ} \mathrm{C}, 254$ $\mathrm{nm}): t_{\mathrm{R}} 18.06 \mathrm{~min}$ (100\%), >99\% ee.

Anal. Calcd for $\mathrm{C}_{15} \mathrm{H}_{14} \mathrm{~N}_{2} \mathrm{OS}$ : C, 66.64; H, 5.22; N, 10.36. Found: C, 66.43; H, 5.36; N, 10.33 .

All spectroscopic data were identical to those of $(R)-3$.

\section{( \pm )-2-(Benzo[d]thiazol-2-ylamino)-2-phenylethanol [( \pm )-3]}

An identical procedure to that outlined for $(R)-3$ using a mixture of $(R)$-2-phenylglycinol [(R)-2; $5.00 \mathrm{~g}, 36.40 \mathrm{mmol}]$ and $(S)$-2-phenylglycinol $[(S)-2 ; 5.00 \mathrm{~g}, 36.40 \mathrm{mmol}]$ gave the title compound $( \pm)-3$ as fluffy white crystals; yield: $14.52 \mathrm{~g}$ (53.71 mmol, 77\%); mp 163$164{ }^{\circ} \mathrm{C}$ (toluene).

HPLC (Chiralcel AD-H, 10\% i-PrOH-hexane, $1.5 \mathrm{~mL} / \mathrm{min}, 40^{\circ} \mathrm{C}, 254$ $\mathrm{nm}): t_{\mathrm{R}} 13.74 \mathrm{~min}(50 \%), 17.33 \mathrm{~min}(50 \%)$.

Anal. Calcd for $\mathrm{C}_{15} \mathrm{H}_{14} \mathrm{~N}_{2} \mathrm{OS}$ : C, 66.64; H, 5.22; N, 10.36. Found: C, 66.49; H, 5.35; N, 10.44 .

All spectroscopic data were identical to those of $(R)-3$.

$(R)-(+)-2-P h e n y l-2,3-d i h y d r o b e n z o[d]$ imidazo[2,1-b]thiazole $[(R)-$ $(+)-B T M ;(R)-(+)-4]$

A $1.0 \mathrm{~L}$ round-bottomed flask containing a stirrer bar was charged with anhydrous $\mathrm{CH}_{2} \mathrm{Cl}_{2}(460 \mathrm{~mL}, 0.1 \mathrm{M})$ followed by $(R)-3(12.42 \mathrm{~g}$, $45.94 \mathrm{mmol}, 1.0$ equiv) with stirring and fitted with a suba seal and exit needle (19 gauge). $\mathrm{Et}_{3} \mathrm{~N}$ ( $25.6 \mathrm{~mL}, 183.8 \mathrm{mmol}, 4.0$ equiv) was added via syringe and the suspension cooled in an ice/water bath. After $10 \mathrm{~min}, \mathrm{MsCl}$ (4.62 mL, $59.72 \mathrm{mmol}, 1.3$ equiv) was added dropwise over ca. $5 \mathrm{~min}$, during which time the suspension dissolved to give a pale yellow solution. The ice/water bath was removed and the reaction mixture stirred for $15 \mathrm{~min}$. The reaction was checked by TLC $\left[\mathrm{CH}_{2} \mathrm{Cl}_{2}-\mathrm{Et}_{2} \mathrm{O} 1: 1, \mathrm{UV}_{254} / \mathrm{KMnO}_{4}, R_{f}(R)-3=\sim 0.28 ; \mathbf{6}=0.61 ; 7=0.81\right]$ and a further portion of $\mathrm{MsCl}(0.36 \mathrm{~mL}, 4.6 \mathrm{mmol}, 0.1$ equiv) added if $(R)-3$ remained (stir $15 \mathrm{~min}$, re-check TLC, and repeat if necessary). It is crucial that all (R)-3 was consumed. Once complete consumption of 
(R)-3 was observed, $i$-PrOH $(9.0 \mathrm{~mL})$ was added and the suba seal replaced by a reflux condenser. The reaction mixture was heated to reflux $\left(50{ }^{\circ} \mathrm{C}\right.$ DrySyn ${ }^{\circledR}$ temperature) overnight (ca. $18 \mathrm{~h}$ ) and checked for completion by ${ }^{1} \mathrm{H}$ NMR analysis. The reaction was quenched with aq 1 $\mathrm{M} \mathrm{NaOH}(200 \mathrm{~mL})$ and the biphasic mixture stirred vigorously for 30 $\mathrm{min}$. The layers were separated and the aqueous layer extracted with $\mathrm{CH}_{2} \mathrm{Cl}_{2}$ (100 mL). The combined organics were washed with brine $(100 \mathrm{~mL})$, dried $\left(\mathrm{MgSO}_{4}\right)$, filtered, and concentrated in vacuo. The crude residue was azeotroped with toluene $(3 \times 50 \mathrm{~mL})$ to remove most of the residual $\mathrm{Et}_{3} \mathrm{~N}$. The residue was triturated with $\mathrm{Et}_{2} \mathrm{O}(200$ $\mathrm{mL}$ ) with sonication and the liquid collected by decantation through a plug of cotton wool. This was repeated with two further portions of $\mathrm{Et}_{2} \mathrm{O}(100 \mathrm{~mL})$, filtering the final portion through the cotton wool. The filter cake was rinsed with a further portion of $\mathrm{Et}_{2} \mathrm{O}(50 \mathrm{~mL})$. The combined ethereal washings were extracted with aq $1 \mathrm{M} \mathrm{HCl}(5 \times 50$ $\mathrm{mL})$ and the combined aqueous layers basified with aq $2 \mathrm{M} \mathrm{NaOH}(\mathrm{pH}$ $>14$ ) at which point a cloudy white precipitate formed. The aqueous layer was extracted with $\mathrm{Et}_{2} \mathrm{O}(3 \times 100 \mathrm{~mL})$ and the combined organics washed with brine $(100 \mathrm{~mL})$. The organic layer was treated with activated charcoal $(\sim 5 \mathrm{~g})$ and dried $\left(\mathrm{MgSO}_{4}\right)$. The suspension was filtered through a pad of Celite, rinsing with further portions of $\mathrm{Et}_{2} \mathrm{O}$ $(2 \times 100 \mathrm{~mL})$. The solvent was removed in vacuo to leave the crude product as a white to pale yellow solid $(9.81 \mathrm{~g})$. This solid was suspended in $\mathrm{Et}_{2} \mathrm{O}$ ( $50 \mathrm{~mL}, \sim 5 \mathrm{~mL} / \mathrm{g}$ crude), scraping any residues from the side of the flask, and heated to reflux for $30 \mathrm{~min}$ (the solid did not completely dissolve). An equal volume of PE $(50 \mathrm{~mL})$ was added and the flask allowed to cool to r.t. with stirring. Once cooled, the solid was collected by vacuum filtration on a $100 \mathrm{~mL}$ sintered glass filter funnel (porosity 3), washing with further portions of PE $(3 \times 50 \mathrm{~mL})$. The solid was dried on the sinter under vacuum for $30 \mathrm{~min}$, then transferred to a $100 \mathrm{~mL}$ round-bottomed flask and dried in vacuo to constant weight to leave pure $(R)-(+)-B T M[(R)-(+)-4](7.83 \mathrm{~g})$ as white to off-white crystals. A second crop $(1.07 \mathrm{~g})$ was obtained by concentration of the filtrate in vacuo and repetition of the above trituration procedure ( $5 \mathrm{~mL} / \mathrm{g} \mathrm{Et}_{2} \mathrm{O}$, equal volume $\mathrm{PE}$ ). Both crops gave identical melting points and optical rotations, so were combined to give $(R)-(+)-B T M[(R)-(+)-4]$ as white crystals; total yield: $8.90 \mathrm{~g}$ (35.27 mmol, 77\%); mp 89-90 ${ }^{\circ} \mathrm{C}$ [ Lit. $^{2} \mathrm{mp} \mathrm{94.5-95}{ }^{\circ} \mathrm{C}\left(\mathrm{Et}_{2} \mathrm{O}-\right.$ hexane)]; $[\alpha]_{D}^{20}+255.4(c 1.05, \mathrm{MeOH})\left\{\right.$ Lit. $\left.^{2}[\alpha]_{D}+256.7(c 1.00, \mathrm{MeOH})\right\}$.

HPLC (Chiralcel AD-H, 10\% $i$-PrOH-hexane, $1.5 \mathrm{~mL} / \mathrm{min}, 40{ }^{\circ} \mathrm{C}, 254$ $\mathrm{nm}): t_{\mathrm{R}} 13.41 \mathrm{~min}(100 \%),>99 \%$ ee.

${ }^{1} \mathrm{H}$ NMR $\left(500 \mathrm{MHz}, \mathrm{CDCl}_{3}\right): \delta=3.72\left[1 \mathrm{H}, \mathrm{dd}, J=8.9,8.1 \mathrm{~Hz}, \mathrm{C}(3) \mathrm{H}^{A} \mathrm{H}^{\mathrm{B}}\right]$, $4.28\left[1 \mathrm{H}, \mathrm{dd}, J=10.2,8.9 \mathrm{~Hz}, \mathrm{C}(3) \mathrm{H}^{\mathrm{A}} \mathrm{H}^{B}\right.$ ], $5.67[1 \mathrm{H}, \mathrm{dd}, J 10.2,8.1 \mathrm{~Hz}$, $\mathrm{C}(2) \mathrm{H}], 6.67(1 \mathrm{H}, \mathrm{dd}, J=8.0,1.1 \mathrm{~Hz}, \mathrm{ArH}), 6.97(1 \mathrm{H}, \mathrm{td}, J=7.7,1.1 \mathrm{~Hz}$, ArH), $7.19(1 \mathrm{H}, \mathrm{td}, J=7.7,1.2 \mathrm{~Hz}, \mathrm{ArH}), 7.27-7.32(1 \mathrm{H}, \mathrm{m}, p-\mathrm{PhH})$, $7.31(1 \mathrm{H}, \mathrm{dd}, J=7.7,1.1 \mathrm{~Hz}, \mathrm{ArH}), 7.35-7.40(4 \mathrm{H}, \mathrm{m}, 0-$, and $m-\mathrm{PhH})$.

${ }^{13} \mathrm{C}\left\{{ }^{1} \mathrm{H}\right\}$ NMR $\left(126 \mathrm{MHz}, \mathrm{CDCl}_{3}\right): \delta=52.6,75.5,108.6,121.6,123.3$, 126.6, 126.7, 127.5, 127.7, 128.9, 137.2, 143.1, 166.8.

Anal. Calcd $\mathrm{C}_{15} \mathrm{H}_{12} \mathrm{~N}_{2} \mathrm{~S}$ : C, 71.40; H, 4.79; N, 11.10. Found: C, 71.28; $\mathrm{H}$, 4.67; N, 11.07 .

${ }^{1} \mathrm{H}$ and ${ }^{13} \mathrm{C}$ NMR data were consistent with literature values. ${ }^{2}$

\section{(S)-(-)-2-Phenyl-2,3-dihydrobenzo[d]imidazo[2,1-b]thiazole $[(S)$ -} (-)-BTM; (S)-(-)-4]

An identical procedure to that outlined for $(R)-(+)-B T M 4$ using $(S)-3$ (13.15 g, $48.64 \mathrm{mmol}), \mathrm{MsCl}(4.89 \mathrm{~mL}, 63.23 \mathrm{mmol})$, and $\mathrm{Et}_{3} \mathrm{~N}(27.1$ $\mathrm{mL}, 194.6 \mathrm{mmol}$ ) in anhydrous $\mathrm{CH}_{2} \mathrm{Cl}_{2}(490 \mathrm{~mL})$ gave $(S)-(-)-\mathrm{BTM}[(S)$ (-)-4] in two crops as white crystals; yield: $8.96 \mathrm{~g}$ (35.51 mmol, 73\%); $\mathrm{mp} 89-90^{\circ} \mathrm{C} ;[\alpha]_{\mathrm{D}}{ }^{20}-256.5$ ( c $\left.0.98, \mathrm{MeOH}\right)$.
HPLC (Chiralcel AD-H, 10\% $i$-PrOH-hexane, $1.5 \mathrm{~mL} / \mathrm{min}, 40{ }^{\circ} \mathrm{C}, 254$ $\mathrm{nm}): t_{\mathrm{R}} 20.98 \mathrm{~min}$ (100\%), >99\% ee.

Anal. Calcd for $\mathrm{C}_{15} \mathrm{H}_{12} \mathrm{~N}_{2} \mathrm{~S}$ : C, 71.40; $\mathrm{H}, 4.79 ; \mathrm{N}, 11.10$. Found: C, 71.25; $\mathrm{H}, 4.91$; N, 10.95 .

All other spectroscopic data were identical to those of $(R)-(+)-$ BTM.

\section{( \pm )-2-Phenyl-2,3-dihydrobenzo[d]imidazo[2,1-b]thiazole $[( \pm)$ - BTM; ( \pm )-4]}

An identical procedure to that outlined for $(R)-(+)-B T M$ using $( \pm)-3$ (14.51 g, $53.67 \mathrm{mmol}), \mathrm{MsCl}(5.40 \mathrm{~mL}, 69.77 \mathrm{mmol})$, and $\mathrm{Et}_{3} \mathrm{~N}(30.0$ $\mathrm{mL}, 214.7 \mathrm{mmol}$ ) in anhydrous $\mathrm{CH}_{2} \mathrm{Cl}_{2}(540 \mathrm{~mL})$ gave ( \pm )-BTM [( \pm )-4]

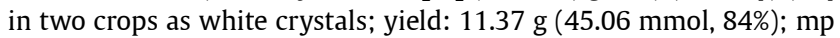
94-95 ${ }^{\circ} \mathrm{C}$.

HPLC (Chiralcel AD-H, 10\% $i$-PrOH-hexane, $1.5 \mathrm{~mL} / \mathrm{min}, 40^{\circ} \mathrm{C}, 254$ $\mathrm{nm}): t_{\mathrm{R}} 13.42 \min$ (50\%), $20.95 \min (50 \%)$.

Anal. Calcd for $\mathrm{C}_{15} \mathrm{H}_{12} \mathrm{~N}_{2} \mathrm{~S}$ : C, 71.40; $\mathrm{H}, 4.79 ; \mathrm{N}, 11.10$. Found: C, 71.28; $\mathrm{H}, 4.91 ; \mathrm{N}, 10.97$.

All other spectroscopic data were identical to those of $(R)-(+)-$ BTM.

(R)-2-[N-(Benzo[d]thiazol-2-yl)methylsulfonamido]-2-phenylethyl Methanesulfonate $[(R)-7]$

A $100 \mathrm{~mL}$ round-bottomed flask containing a stirrer bar was charged with $(R)-3$ (500 mg, $1.85 \mathrm{mmol}, 1.0$ equiv) and anhydrous $\mathrm{CH}_{2} \mathrm{Cl}_{2}(20$ $\mathrm{mL}$ ). $\mathrm{Et}_{3} \mathrm{~N}$ (1.03 mL, $7.40 \mathrm{mmol}, 4.0$ equiv) was added, the suspension cooled in an ice/water bath, and $\mathrm{MsCl}(0.36 \mathrm{~mL}, 4.63 \mathrm{mmol}, 2.5$ equiv) added dropwise over $2 \mathrm{~min}$. The reaction mixture was stirred for 10 min, checked by TLC $\left(\mathrm{CH}_{2} \mathrm{Cl}_{2}-\mathrm{Et}_{2} \mathrm{O}, 1: 1\right)$ and quenched with sat. aq $\mathrm{NaHCO}_{3}(20 \mathrm{~mL})$. The layers were separated and the aqueous layer extracted with $\mathrm{CH}_{2} \mathrm{Cl}_{2}(20 \mathrm{~mL})$. The combined organics were washed with aq $0.1 \mathrm{M} \mathrm{HCl}(30 \mathrm{~mL})$, dried $\left(\mathrm{MgSO}_{4}\right)$, and filtered. The solvent was removed in vacuo to leave the crude product, which was purified by flash chromatography on silica gel $\left(\mathrm{CH}_{2} \mathrm{Cl}_{2}\right)$ to leave $(R)-7$ as a colourless foam; yield: $661 \mathrm{mg}(1.55 \mathrm{mmol}, 84 \%) ;[\alpha]_{D}^{20}+31.8(c 1.0, \mathrm{CH}-$ $\left.\mathrm{Cl}_{3}\right)$.

IR (film): 3028, 2936, 1636, 1580, 1454, 1352, 1244, 1173, 1157, $1034,961 \mathrm{~cm}^{-1}$.

${ }^{1} \mathrm{H}$ NMR (400 MHz, $\mathrm{CDCl}_{3}$ ): $\delta=2.97\left(3 \mathrm{H}, \mathrm{s}, \mathrm{OSO}_{2} \mathrm{CH}_{3}\right), 3.67(3 \mathrm{H}, \mathrm{m}$, $\left.\mathrm{NSO}_{2} \mathrm{CH}_{3}\right), 4.33-4.52\left[2 \mathrm{H}, \mathrm{m}, \mathrm{C}(2) \mathrm{H}\right.$ and $\left.\mathrm{C}(1) \mathrm{H}^{A} \mathrm{H}^{\mathrm{B}}\right], 4.55[1 \mathrm{H}, \mathrm{dd}, J=$ 8.4, 7.2 Hz, C(1) $\mathrm{H}^{A} H^{B}$ ], $7.12(1 \mathrm{H}, \mathrm{td}, J=7.6,1.1 \mathrm{~Hz}, \mathrm{ArH}), 7.20-7.27$ (2 $\mathrm{H}, \mathrm{m}, \mathrm{ArH}), 7.30-7.40(3 \mathrm{H}, \mathrm{m}, \mathrm{m}-\mathrm{and} p-\mathrm{PhH}), 7.43-7.46(2 \mathrm{H}, \mathrm{m}, o-$ $\mathrm{PhH}), 7.98(1 \mathrm{H}, \mathrm{dd}, J=8.5,0.7 \mathrm{~Hz}, \mathrm{ArH})$.

${ }^{13} \mathrm{C}\left\{{ }^{1} \mathrm{H}\right\}$ NMR (100 MHz, $\left.\mathrm{CDCl}_{3}\right): \delta=37.7,42.7,68.1,73.8,115.8,122.3$, $122.4,124.6,126.9,127.8,128.6,129.0,136.0,137.2,154.8$.

HRMS (ESI): $m / z\left[M+\mathrm{H}^{+}\right]$calcd for $\mathrm{C}_{17} \mathrm{H}_{19} \mathrm{~N}_{2} \mathrm{O}_{5} \mathrm{~S}_{3}$ : 427.0451; found: $427.0441(-2.5 \mathrm{ppm})$.

\section{Cyclisation of $(R)-7$ To Form $(R)$-BTM}

A $50 \mathrm{~mL}$ round-bottomed flask containing a stirrer bar and fitted with a reflux condenser was charged with $(R)-7(650 \mathrm{mg}, 1.52 \mathrm{mmol}, 1.0$ equiv), $\mathrm{Et}_{3} \mathrm{~N}\left(0.64 \mathrm{~mL}, 4.57 \mathrm{mmol}, 3.0\right.$ equiv), anhydrous $\mathrm{CH}_{2} \mathrm{Cl}_{2}(15$ $\mathrm{mL})$, and $\mathrm{MeOH}(1.0 \mathrm{~mL})$. The resulting solution was heated to reflux overnight, allowed to cool, and quenched with aq $1 \mathrm{M} \mathrm{NaOH}(20 \mathrm{~mL})$. The layers were separated and the aqueous layer was extracted with $\mathrm{CH}_{2} \mathrm{Cl}_{2}(20 \mathrm{~mL})$. The combined organics were dried $\left(\mathrm{MgSO}_{4}\right)$, filtered, and the solvent removed in vacuo to leave the crude product, which was purified by flash chromatography on silica gel $\left(\mathrm{CH}_{2} \mathrm{Cl}_{2} \rightarrow 1: 4\right.$ $\mathrm{Et}_{2} \mathrm{O}-\mathrm{CH}_{2} \mathrm{Cl}_{2}$ ) to leave pure noncrystalline $(R)$-BTM $[(R)-4]$ as a white powder; yield: $341 \mathrm{mg}$ (1.35 mmol, 89\%). This material was not recrystallised. 
${ }^{1} \mathrm{H}$ NMR spectrum was identical to that prepared by the optimised route.

\section{Acknowledgment}

We thank the Royal Society for a University Research Fellowship (ADS), the EPSRC (EP/J018139/1, DSBD), and GSK (Case award to SRS) for funding. We also thank the European Research Council under the European Union's Seventh Framework Programme (FP7/2007-2013) ERC grant agreement number 279850 for additional funding, and the EPSRC UK National Mass Spectrometry Service Centre at Swansea University.

\section{Supporting Information}

Supporting information for this article is available online at http://dx.doi.org/10.1055/s-0034-1378931.

\section{References}

(1) For an excellent review, see: Taylor, J. E.; Bull, S. D.; Williams, J. M. J. Chem. Soc. Rev. 2012, 41, 2109.

(2) Birman, V. B.; Li, X. Org. Lett. 2006, 8, 1351.

(3) (a) Thienpont, D.; Vanparijs, O. F. J.; Raeymaekers, A. H. M.; Vandenberk, J.; Demoen, P. J. A.; Allewijn, F. T. N.; Marsboom, R. P. H.; Niemegeers, C. J. E.; Schellekens, K. H. L.; Janssen, P. A. J. Nature 1966, 209, 1084. (b) Raeymaekers, A. H. M.; Allewijn, F. T. N.; Vandenberk, J.; Demoen, P. J. A.; Van Offenwert, T. T. T.; Janssen, P. A. J. J. Med. Chem. 1966, 9, 545.

(4) For the use of achiral DHPB-based catalysts, see: (a) Kobayashi, M.; Okamoto, S. Tetrahedron Lett. 2006, 47, 4347. (b) Birman, V. B.; Li, X.; Han, Z. Org. Lett. 2007, 9, 37. For the introduction of HBTM, see: (c) Birman, V. B.; Li, X. Org. Lett. 2008, 10, 1115. For the effect of configuration in HBTM-2 and derivatives, see: (d) Yang, X.; Birman, V. B. Adv. Synth. Catal. 2009, 351, 2301. For the effect of stereodirecting group, see: (e) Joannesse, C.; Johnston, C. P.; Concellón, C.; Simal, C.; Philp, D.; Smith, A. D. Angew. Chem. Int. Ed. 2009, 48, 8914. (f) Belmessieri, D.; Joannesse, C.; Woods, P. A.; MacGregor, C.; Jones, C.; Campbell, C. D.; Johnston, C. P.; Duguet, N.; Concellón, C.; Bragg, R. A.; Smith, A. D. Org. Biomol. Chem. 2011, 9, 559. Alternatively Okamoto and co-workers have used 4-Mes-DHPB in asymmetric Steglich rearrangements: (g) Viswambharan, B.; Okimura, T.; Suzuki, S.; Okamoto, S. J. Org. Chem. 2011, 76, 6678.

(5) (a) Birman, V. B.; Guo, L. Org. Lett. 2006, 8, 4859. (b) Birman, V. B.; Jiang, H.; Li, X.; Guo, L.; Uffman, E. W. J. Am. Chem. Soc. 2006, 128, 6536. (c) Birman, V. B.; Jiang, H.; Li, X. Org. Lett. 2007, 9, 3237. (d) Yang, X.; Lu, G.; Birman, V. B. Org. Lett. 2010, 12, 892. (e) Bumbu, V. D.; Birman, V. B. J. Am. Chem. Soc. 2011, 133, 13902. (f) Yang, X.; Bumbu, V. D.; Liu, P.; Li, X.; Jiang, H.; Uffman, E. W.; Guo, L.; Zhang, W.; Jiang, X.; Houk, K. N.; Birman, V. B. J. Am. Chem. Soc. 2012, 134, 17605. (g) Yang, X.; Liu, P.; Houk, K. N.; Birman, V. B. Angew. Chem. Int. Ed. 2012, 51, 9638. (h) Liu, P.; Yang, X.; Birman, V. B.; Houk, K. N. Org. Lett. 2012, 14,
3288. (i) Li, X.; Jiang, H.; Uffman, E. W.; Guo, L.; Zhang, Y.; Yang, X.; Birman, V. B. J. Org. Chem. 2012, 77, 1722. (j) Bumbu, V. D.; Yang, X.; Birman, V. B. Org. Lett. 2013, 15, 2790.

(6) (a) Shiina, I.; Nakata, K. Tetrahedron Lett. 2007, 48, 8314. (b) Shiina, I.; Nakata, K.; Onda, Y.-s. Eur.J. Org. Chem. 2008, 5887. (c) Shiina, I.; Nakata, K.; Sugimoto, M.; Onda, Y.-S.; Iizumi, T.; Ono, K. Heterocycles 2009, 77, 801. (d) Nakata, K.; Onda, Y.-s.; Ono, K.; Shiina, I. Tetrahedron Lett. 2010, 51, 5666. (e) Shiina, I.; Nakata, K.; Ono, K.; Onda, Y.-s.; Itagaki, M. J. Am. Chem. Soc. 2010, 132, 11629. (f) Nakata, K.; Shiina, I. Heterocycles 2010, 80, 169. (g) Shiina, I.; Nakata, K.; Ono, K.; Sugimoto, M.; Sekiguchi, A. Chem. Eur. J. 2010, 16, 167. (h) Nakata, K.; Sekiguchi, A.; Shiina, I. Tetrahedron: Asymmetry 2011, 22, 1610. (i) Nakata, K.; Ono, K.; Shiina, I. Heterocycles 2011, 82, 1171. (j) Tengeiji, A.; Nakata, K.; Ono, K.; Shiina, I. Heterocycles 2012, 86, 1227. (k) Shiina, I.; Nakata, K.; Ono, K.; Mukaiyama, T. Helv. Chim. Acta 2012, 95, 1891. (1) Shiina, I.; Ono, K.; Nakata, K. Catal. Sci. Technol. 2012, 2, 2200. (m) Tengeiji, A.; Shiina, I. Molecules 2012, 17, 7356. (n) Shiina, I.; Umezaki, Y.; Kuroda, N.; Iizumi, T.; Nagai, S.; Katoh, T. J. Org. Chem. 2012, 77, 4885. (o) Shiina, I.; Ono, K.; Nakahara, T. Chem. Commun. 2013, 49, 10700. (p) Nakata, K.; Gotoh, K.; Ono, K.; Futami, K.; Shiina, I. Org. Lett. 2013, 15, 1170.

(7) (a) Zhou, H.; Xu, Q.; Chen, P. Tetrahedron 2008, 64, 6494. (b) Xu, Q.; Zhou, H.; Geng, X.; Chen, P. Tetrahedron 2009, 65, 2232. (c) Chen, P.; Zhang, Y.; Zhou, H.; Xu, Q. Huaxue Xuebao 2010, 68, 1431. (d) Ball, J. C.; Brennan, P.; Elsunaki, T. M.; Jaunet, A.; Jones, S. Tetrahedron: Asymmetry 2011, 22, 253. (e) Matsumoto, T.; Urano, Y.; Takahashi, Y.; Mori, Y.; Terai, T.; Nagano, T. J. Org. Chem. 2011, 76, 3616. (f) Klauck, M. I.; Patel, S. G.; Wiskur, S. L. J. Org. Chem. 2012, 77, 3570.

(8) Dietz, F. R.; Gröger, H. Synthesis 2009, 4208.

(9) Clark, R. W.; Deaton, T. M.; Zhang, Y.; Moore, M. I.; Wiskur, S. L. Org. Lett. 2013, 15, 6132.

(10) Cortez, G. S.; Tennyson, R. L.; Romo, D. J. Am. Chem. Soc. 2001, 123, 7945

(11) (a) Purohit, V. C.; Matla, A. S.; Romo, D. J. Am. Chem. Soc. 2008, 130, 10478. (b) Leverett, C. A.; Purohit, V. C.; Romo, D. Angew. Chem. Int. Ed. 2010, 49, 9479.

(12) (a) Belmessieri, D.; Morrill, L. C.; Simal, C.; Slawin, A. M. Z.; Smith, A. D. J. Am. Chem. Soc. 2011, 133, 2714. (b) Morrill, L. C.; Lebl, T.; Slawin, A. M. Z.; Smith, A. D. Chem. Sci. 2012, 3, 2088. (c) Simal, C.; Lebl, T.; Slawin, A. M. Z.; Smith, A. D. Angew. Chem. Int. Ed. 2012, 51, 3653. (d) Morrill, L. C.; Douglas, J.; Lebl, T.; Slawin, A. M. Z.; Fox, D. J.; Smith, A. D. Chem. Sci. 2013, 4, 4146. (e) Belmessieri, D.; Cordes, D. B.; Slawin, A. M. Z.; Smith, A. D. Org. Lett. 2013, 15, 3472. (f) Robinson, E. R. T.; Fallan, C.; Simal, C.; Slawin, A. M. Z.; Smith, A. D. Chem. Sci. 2013, 4, 2193. (g) Stark, D. G.; Morrill, L. C.; Yeh, P.-P.; Slawin, A. M. Z.; O'Riordan, T. J. C.; Smith, A. D. Angew. Chem. Int. Ed. 2013, 52, 11642. (h) Morrill, L. C.; Ledingham, L. A.; Couturier, J.-P.; Bickel, J.; Harper, A. D.; Fallan, C.; Smith, A. D. Org. Biomol. Chem. 2014, 12, 624. (i) Yeh, P.-P.; Daniels, D. S. B.; Cordes, D. B.; Slawin, A. M. Z.; Smith, A. D. Org. Lett. 2014, 16, 964. (j) Smith, S. R.; Douglas, J.; Prevet, H.; Shapland, P.; Slawin, A. M. Z.; Smith, A. D. J. Org. Chem. 2014, 79, 1626. (k) Morrill, L. C.; Smith, S. M.; Slawin, A. M. Z.; Smith, A. D. J. Org. Chem. 2014, 79, 1640. (1) Smith, S. R.; Leckie, S. M.; Holmes, R.; Douglas, J.; Fallan, C.; 
Shapland, P.; Pryde, D.; Slawin, A. M. Z.; Smith, A. D. Org. Lett. 2014, 16, 2506. (m) Belmessieri, D.; de la Houpliere, A.; Calder, E. D. D.; Taylor, J. E.; Smith, A. D. Chem. Eur. J. 2014, 20, 9762.

(13) West, T. H.; Daniels, D. S. B.; Slawin, A. M. Z.; Smith, A. D. J. Am. Chem. Soc. 2014, 136, 4476.

(14) (a) Liu, G.; Shirley, M. E.; Van K, N.; McFarlin, R. L.; Romo, D. Nat. Chem. 2013, 5, 1049. (b) Abbasov, M. E.; Hudson, B. M.; Tantillo, D. J.; Romo, D. J. Am. Chem. Soc. 2014, 136, 4492.

(15) (a) Xu, Q.; Zhou, H.; Chen, P. Huaxue Shiji 2010, 32, 293. (b) Xu, Q.; Zhou, H.; Chen, P. Huaxue Shiji 2010, 32, 298.

(16) Okamoto, S.; Sakai, Y.; Watanabe, S.; Nishi, S.; Yoneyama, A.; Katsumata, H.; Kosaki, Y.; Sato, R.; Shiratori, M.; Shibuno, M.; Shishido, T. Tetrahedron Lett. 2014, 55, 1909.

(17) From TCI-UK Ltd.: (R)-BTM P/N: B3296, £ 94.20/1 g; (S)-BTM $\mathrm{P} / \mathrm{N}: \mathrm{B} 3549, £ 83.45 / 1 \mathrm{~g}$ (accessed 22/08/2014).

(18) Racemic 2-phenylglycinol is prohibitively expensive and was obtained by mixing equal amounts of the commercially available $(R)$ - and $(S)$-2-phenylglycinols.
(19) See experimental for details.

(20) The site of N-mesylation was determined by ${ }^{1} \mathrm{H}_{-}{ }^{15} \mathrm{~N}$ HMBC spectroscopy, supported by DFT calculations for the ${ }^{15} \mathrm{~N}$ chemical shifts. See Supporting Information for details.

(21) Birman states that the addition of $\mathrm{MeOH}$ serves to quench additional $\mathrm{MsCl}$, see ref. 1 .

(22) $\mathrm{MeOH}$ was replaced with $i$-PrOH as it was considered that the by-product $i$-PrOMs from reaction with sulfene would be less reactive as an alkylating agent than MeOMs, thereby reducing polymeric impurities.

(23) Armarego, W. L. F.; Chai, C. L. L. Purification of Laboratory Chemicals, 6th ed.; Butterworth-Heinemann: Oxford, 2009.

(24) GC analysis indicated $>95 \%$ conversion of 2-chlorobenzothiazole against 0 -dichlorobenzene as the internal standard. Approximately $200 \mu \mathrm{L}$ samples of the reaction mixture at $t=0$ and $24 \mathrm{~h}$ were taken and diluted to $\sim 1.5 \mathrm{~mL}$ in $\mathrm{CH}_{2} \mathrm{Cl}_{2}$ for analysis. 